Old Dominion University

ODU Digital Commons

Teaching \& Learning Faculty Publications

Teaching \& Learning

2017

\title{
Making a Case for Case-Based Teaching in Data Literacy
}

Derek R. Riddle

Jori Beck

Old Dominion University, jbeck@odu.edu

Joseph John Morgan

Nancy Brown

Heather Whitesides

Follow this and additional works at: https://digitalcommons.odu.edu/teachinglearning_fac_pubs

Part of the Teacher Education and Professional Development Commons, and the Vocational Education Commons

Original Publication Citation

Riddle, D. R., Beck, J. S., Morgan, J. J., Brown, N., \& Whitesides, H. (2017). Making a case for case-based teaching in data literacy. Kappa Delta Pi Record, 53(3), 131-133. doi:10.1080/00228958.2017.1334479

This Article is brought to you for free and open access by the Teaching \& Learning at ODU Digital Commons. It has been accepted for inclusion in Teaching \& Learning Faculty Publications by an authorized administrator of ODU Digital Commons. For more information, please contact digitalcommons@odu.edu. 
Research Reports

\section{Making a Case for Case-Based Teaching in Data Literacy}

by Derek R. Riddle, Jori Beck, Joseph John Morgan, Nancy Brown, and Heather Whitesides

Derek R. Riddle is a doctoral student at the University of Nevada, Las Vegas. His areas of interest include teacher professional development, classroom management, grading practices, and education policy. Email:

driddle@unlv.nevada.edu

Jori Beck is an Assistant Professor of teacher education at the University of Nevada, Las Vegas. Her areas of interest and specialization include clinical teacher preparation, teacher residencies, and qualitative research. Email: jori.beck@unlv.edu

Joseph John Morgan is an Assistant Professor of Special Education in the Department of Educational and Clinical Studies at the University of Nevada, Las Vegas. His research focuses on improving the social-emotional outcomes of students with disabilities in urban schools. Email: joseph.morgan@unlv.edu

Nancy Brown is a Faculty in Residence in the Department of Educational and Clinical and doctoral student at the University of Nevada, Las Vegas. Her areas of interest are behavior management, inclusion, data-based decision making, teacher preparation, and teacher evaluation.Email: nancy.brown@unlv.edu

Heather Whitesides is an Education Specialist for the National Park Service. She specializes in multicultural environmental education. Email: heather.whitesides@unlv.edu

\section{Abstract}

Building on a study conducted by the authors, this article provides strategies for teaching data literacy and outlines the case-based teaching method as an effective way of developing data-literate teachers.

Keywords: case-based teaching, data literacy, teacher education

Teachers should master many forms of knowledge and skills to effectively execute their jobs. These include two key skills that can improve both teacher practice and student achievement: (a) the use of data to inform instruction; and (b) the ability to develop actionable, differentiated instruction through data-based decision-making processes (DBDM). These two skills are referred to as data literacy (Gummer \& Mandinach, 2015) and are becoming a necessity for teachers.

For instance, the National Council for Accreditation of Teacher Education (NCATE; 2008) requires that teacher educators assess teacher candidates' ability to "analyze student, classroom, and school performance data and make data-driven decisions about strategies for teaching and learning so that all students learn" (p. 19). In Nevada, teachers are evaluated on their ability to "plan on-going [sic] learning opportunities based on evidence of 
all students' current learning status" and "adapt actions based on evidence generated in the lesson for all students" (original emphasis; Nevada Department of Education, 2014, p. 1). Moreover, professional learning communities (PLCs) are becoming commonplace in $\mathrm{K}-12$ schools and, within these meetings, teams are often required to discuss student achievement data. In addition, the Every Student Succeeds Act (ESSA, 2015) directs state and local educational agency leaders to provide professional development that enhances teachers' dataliteracy skills (i.e., pp. 64, 129). Thus, data proficiency is required by all levels of policy.

A growing body of literature supports the role of data literacy in improving teacher quality and, ultimately, student achievement. For example, Schildkamp, Lai, and Earl (2013) cited studies indicating that school leaders who embedded data-literacy skills in their professional learning and used data with high frequency to evaluate progress made significant improvements in student achievement. While this is compelling evidence, much more needs to be done to develop data literacy in teachers, as this construct is often absent from teacherpreparation programs (Mandinach, Friedman, \& Gummer, 2015).

While there has been a clear call for supporting data-literacy proficiency, the question remains: What is the best way to help teachers acquire data literacy? Recently, our research team conducted a study to determine when to introduce data-literacy training into the teacher-education continuum (i.e., preservice or inservice). Our mixed-methods study involved introducing principles of data literacy in courses taught to three different participant groups: two master's level special education courses and one undergraduate elementary assessment course. Participants in our study expressed a preference for learning about data literacy early in their programs and continuously refining their skills as they progress, while also having the opportunity to apply their learning through continual exposure and practice using specific, real-world examples (Beck, Morgan, Whitesides, Brown, \& Riddle, in preparation). Case-based teaching answers these calls.

\section{Case-Based Teaching}

Researchers have found numerous benefits of using case-based teaching in teacher education, including applied theoretical and practical knowledge to specific school contexts, increased metacognition about their teaching, and increased efficiency in framing classroom dilemmas (Darling-Hammond \& Hammerness, 2002). Leaders at Michigan State University (n.d.) defined case-based teaching as "an active learning strategy in which students read and discuss complex, real-life scenarios that call on their analytical thinking skills and decision-making" (para. 1). For example, a teacher educator in a math methods course could provide teacher candidates with a set of hypothetical data from a pretest measuring defined mathematical standards for a specific student. This case could provide an opportunity for teacher candidates to learn how to analyze and interpret data. The instructor of the math methods course could then, after infusing data-literacy skills, have the teachers use the knowledge gained through their analysis to design lesson plans based on their interpretations of the pretest score. 
Although there are many approaches for developing cases to be used in instructing teachers and teacher candidates on data-literacy practices, Shulman (1992, p. 18) suggested "incomplete cases" as being potentially beneficial to teaching critical skills such as data literacy. The incomplete case is a depiction of only a partial account; for example, inservice teachers could be presented with several pieces of data for a student. These teachers could analyze and discuss potential instructional decisions for the student based on the presented data before learning how the teacher in the case responded to these data.

Teacher educators initially should focus on three main steps in developing data-literacy cases:

1. Decide what principles of data literacy should be incorporated in their course;

2. Determine teacher candidates and/or inservice teachers knowledge and skills related to data literacy; and

3. Select or design materials for the case to align with the chosen principle.

\section{Principles of Data Literacy}

Members of the National Forum on Education Statistics (2012) created the data inquiry cycle as a guide to help teacher educators teach data-literacy skills. They suggested five principles to follow in a cyclical process: (a) seek information; (b) access and gather data; (c) analyze and interpret data; (d) act; and (e) evaluate. These principles are expanded on in Table 1. These principles can be taught in an isolated fashion. For instance, if a teacher educator desires to help teacher candidates determine the reliability and validity of data, he or she may begin there.

\section{$* * *$ insert table 1 about here}

\section{Determining Baseline Knowledge}

Once the specific principles are identified, teacher educators should determine the level of knowledge and skill that teacher candidates and inservice teachers have regarding data literacy. This may be accomplished by providing inservice teachers a pre-test or determining how the principle would best fit in a teacher candidate's program sequence. When designing case-based teaching materials, the information presented must be suited to teachers' prior understanding of principles of data literacy. While beyond the scope of this manuscript, teacher educators could employ a variety of techniques to determine baseline knowledge (e.g., discussions, creation of a specific pretest, analysis of previous and subsequent course materials). The goal is to help teacher candidates and inservice teachers become proficient in their use of data-literacy skills. Therefore, the use of culminating projects in assessment courses, for example, or capstone projects included with student teaching assessments may provide teacher educators with data on teacher candidates' proficiency of these skills. Programmatic decisions of what principles and when, where, and how they should be implemented in a preservice program should be carefully considered in teacher education program committees. 


\section{Selecting and Designing Materials}

Teacher educators can consider many ways to create incomplete cases for teaching principles of data literacy and creating authentic learning experiences. Whatever methods are chosen to create the cases, it is important to ensure that the designed cases pair with the principle of data literacy being targeted. For example, if a teacher educator is teaching the principle of seeking information in a secondary science teacher education program, the case may highlight achievement gaps identified in a high school science assessment and encourage teacher candidates to hypothesize additional data points that may be needed to fully understand where to target instruction. Table 1 includes sample characteristics that should be included in each case to best match the materials chosen for the case and the principle being addressed.

\section{Conclusion}

Shulman (1992) concluded that case-based teaching could be "a strategy for overcoming many of the most serious deficiencies in education" (p. 28). Current educational policy documents (e.g., Data Quality Campaign, 2014; ESSA, 2015) indicate that data literacy is deficient in teacher education. If teachers are to meet the new mandates set forth by these initiatives, case-based teaching may be an effective method to achieve the expectation of preparing a data-literate teacher workforce. Case-based teaching allows for work with authentic data and provides teacher educators opportunities to teach data-literacy principles using discrete methods that accommodate corrective feedback. Teacher educators should use curriculum maps or other matrices to consider and determine how and when to infuse data-literacy skills, along with which subset of skills to include, into the preparation of their teacher candidates. These instructional and programmatic decisions can strengthen teacher candidates' abilities to engage in high-quality data practices.

\section{References}

Beck, J. S., Morgan, J. J., Whitesides, H., Brown, N., \& Riddle, D. R. (in preparation). "Asking, learning, seeking out": A mixed methods exploration of data literacy.

Darling-Hammond, L., \& Hammerness, K. (2002). Toward a pedagogy of cases in teacher education. Teaching Education, 13(2), 125-135. doi:10.1080/1047621022000007549

Data Quality Campaign. (2014, February). Teacher data literacy: It's about time. Washington, DC: Author. Retrieved from http://2pido73em67o3eytaq1cp8au.wpengine.netdna-cdn.com/wp-content/uploads/2016/03/DQCData-Literacy-Brief.pdf

Every Student Succeeds Act, Pub. L. No. 114-95 § 1002, Stat. 1802 (2015).

Gummer, E. S., \& Mandinach, E. B. (2015). Building a conceptual framework for data literacy. Teachers College Record, 117(4), 1-22. 
Mandinach, E., Friedman, J. M., \& Gummer, E. (2015). How can schools of education help to build educators' capacity to use data? A systemic view of the issue. Teachers College Record, 117(4), 1-50.

Michigan State University. (n.d). Case-based teaching. Retrieved from http://fod.msu.edu/oir/case-based-teaching National Council for Accreditation of Teacher Education. (2008, February). Professional standards for the accreditation of teacher preparation institutions. Retrieved from http://www.ncate.org/Portals/0/documents/Standards/NCATE\%20Standards\%202008.pdf

National Forum on Education Statistics. (2012). Forum guide to taking action with education data [NFES 2013-801]. Washington, DC: National Center for Education Statistics.

Nevada Department of Education. (2014). Nevada educator performance framework rubrics: Teacher instructional practice standards and indicators. Retrieved from http://www.doe.nv.gov/Educator_Effectiveness/Educator_Develop_Support/NEPF/Rubrics

Schildkamp, K., Lai, M. K., \& Earl, L. M. (Eds.). (2013). Data-based decision making in education: Challenges and opportunities. New York, NY: Springer.

Shulman, L. S. (Ed.). (1992). Toward a pedagogy of cases. In J. H. Shulman (Ed.), Case methods in teacher education (pp. 1-30). New York, NY: Teachers College Press. 
Table 1. Considerations and Sample Materials for Case-Based Teaching

\begin{tabular}{|c|c|c|}
\hline $\begin{array}{l}\text { Principle of data-based } \\
\text { decision-making processes }\end{array}$ & Case-based teaching materials & $\begin{array}{l}\text { Case-based teaching materials for } \\
\text { secondary content areas case study }\end{array}$ \\
\hline Seek information & $\begin{array}{l}\text { A skill that needs to be taught and the } \\
\text { information that would need to be gathered } \\
\text { to determine the best approach for teaching } \\
\text { that skill }\end{array}$ & $\begin{array}{l}\text { Diagnostic assessments focused on writing } \\
\text { skills }\end{array}$ \\
\hline Access and gather data & $\begin{array}{l}\text { Different types of assessments that could be } \\
\text { given to gain information related to the } \\
\text { global skill and how to best get that data } \\
\text { from students }\end{array}$ & $\begin{array}{l}\text { Student academic records with previous } \\
\text { math scores and level of achievement } \\
\text { compared to the standards }\end{array}$ \\
\hline Analyze and interpret data & $\begin{array}{l}\text { Specific questions that should be asked } \\
\text { when data are collected to determine } \\
\text { students' relative strengths, needs, and } \\
\text { interests related to a topic }\end{array}$ & $\begin{array}{l}\text { Discovery by performing arts teacher from } \\
\text { previous acting performances that the } \\
\text { student has consistently struggled } \\
\text { identifying and enacting character emotions }\end{array}$ \\
\hline Act & $\begin{array}{l}\text { Design of lessons or units of instruction } \\
\text { to address the ideas found in the } \\
\text { analysis and interpretation of data. }\end{array}$ & $\begin{array}{l}\text {-Teacher designs a Tier II intervention, } \\
\text { focused on reviewing and re-teaching } \\
\text { explaining the relationship between } \\
\text { potential energy and kinetic energy }\end{array}$ \\
\hline Evaluate & $\begin{array}{l}\text { Various assessment techniques to } \\
\text { determine the impact of the lessons or units } \\
\text { of instruction, as well as refine instruction } \\
\text { and intervention to increase impact }\end{array}$ & $\begin{array}{l}\text { Decision by history teacher to progress } \\
\text { monitor targeted skills (e.g., analyze primary } \\
\text { and secondary sources for historical } \\
\text { perspective) every } 2 \text { weeks to measure } \\
\text { growth, and, if no growth is made after } 4 \\
\text { weeks, modify intervention }\end{array}$ \\
\hline
\end{tabular}

\begin{tabular}{lll}
\hline $\begin{array}{c}\text { Principle of } \\
\text { DBDM }\end{array}$ & \multicolumn{1}{c}{ Case-Based Teaching Materials } & $\begin{array}{c}\text { Case-Based Teaching Materials for Secondary } \\
\text { Content Areas Case Study }\end{array}$ \\
\hline $\begin{array}{l}\text { Seek } \\
\text { information }\end{array}$ & $\begin{array}{l}\text { A skill that needs to be taught and the } \\
\text { information that would need to be gathered } \\
\text { in order to determine the best approach for } \\
\text { teaching that skill. }\end{array}$ & $\begin{array}{l}\text {-Diagnostic assessments focused on writing } \\
\text { skills }\end{array}$ \\
\end{tabular}

Access and Different types of assessments that could be gather data

Analyze and interpret data

Specific questions that should be asked when data are collected to determine students' relative strengths, needs, and interests related to a topic.

Act

Design of lessons or units of instruction to address the ideas found in the analysis and interpretation of data.

Evaluate given to gain information related to the global skill and how to best get that data from students.
-Review student academic records for previous math scores and level of achievement compared to the standards

-Performing arts teacher discovers from previous acting performances that the student has consistently struggled identifying and enacting character emotions

-Teacher designs a Tier II intervention, focused on reviewing and re-teaching explaining the relationship between potential energy and kinetic energy

-History teacher decides to progress monitor targeted skills (e.g., analyzing primary and secondary sources for historical perspective) 
instruction and intervention to increase impact. every two weeks to measure growth. If no growth is made after four weeks, teacher will modify intervention 